\title{
Infrastructure Performance and Reform in Developing and Transition Economies: Evidence from a Survey of Productivity Measures
}

\author{
Antonio Estache \\ World Bank and \\ ECARES, Université Libre de Bruxelles \\ Sergio Perelman \\ CREPP, Université de Liège \\ Lourdes Trujillo \\ DAEA, Universidad de Las Palmas de Gran Canaria
}

\begin{abstract}
World Bank Policy Research Working Paper 3514, February 2005
The Policy Research Working Paper Series disseminates the findings of work in progress to encourage the exchange of ideas about development issues. An objective of the series is to get the findings out quickly, even if the presentations are less than fully polished. The papers carry the names of the authors and should be cited accordingly. The findings, interpretations, and conclusions expressed in this paper are entirely those of the authors. They do not necessarily represent the view of the World Bank, its Executive Directors, or the countries they represent. Policy Research Working Papers are available online at http://econ.worldbank.org.
\end{abstract}

The authors are grateful to Antonio Alvarez, Phil Burns, Tim Coelli, Claude Crampes, Andres Gomez-Lobo, Emili Grifell, Augustin Mpapa Mbangala, Marcelo Resende, Martin RodriguezPardina, Martin Rossi , Christian Ruzzier, German Sember and Ronaldo Seroa da Motta for useful discussions. 


\section{Introduction}

Until the early 1990s or so, infrastructure industries - energy, ports, railways, roads, telecommunications and water \& sewerage - were generally almost exclusively a public sector responsibility. This has changed. Private corporations - often not localare now an actor in roughly $40-50 \%$ of the countries of the world in some key dimension of large-scale service delivery - the average is somewhat higher for developed countries than for developing countries and for some sectors than for others as discussed later. ${ }^{1}$

For developing and transition economies, there were at least three main drivers behind this transformation. The first was a change in ideology. The high profile of the, then, very atypical 1970s British and Chilean experiences with market oriented privatization, were the results of political reversals in these two countries. These real life laboratories of the competition cum privatization experiments eased the large-scale replications of the 1990s. British and Chilean experts traveled the world during the 1980s "selling" their experiences to curious audiences from Africa, Latin America, Asia and later Eastern Europe.

The second change engine was technological. The telecommunication revolution is well known and has been internalized in the most remote areas of the world. Not quite as spectacular as in telecoms, technological changes have however also reached almost all other sectors in poor countries. From more cost effective small water systems to spectacularly performing low cost small-scale solar generators, technological progress is slowly but surely changing the market structure in water and energy service delivery in developing countries. The transport sector has not been left behind. Its most obvious technological change is the explosion of the containerization of a large share of the freight traffic. Equipment, such as cranes, rolling stocks and even trucks, are indeed also adjusting as a result. Most of these changes have allowed major sector restructuring and in particular the unbundling of competitive segments of businesses from the residual monopoly segments. The implementation of the competition dimension of the ideological revolution was, to a large extent, allowed by this technological revolution across sectors.

The third engine of reform is the fiscal crisis of the 1980s to the mid-1990s in most developing and transition economies. ${ }^{2}$ Governments could no longer afford the high costs of the historically high inefficiency levels and of the resulting subsidy demands of the sector. Moreover, governments had long stopped significant investment in the sector. As a consequence service coverage rates had been stagnating, at best catching up with population growth. Many of the public enterprises were no longer financially capable of ensuring the most basic maintenance of the assets. The public sector financing constraints were so binding that the choice was between rationing and increased private sector

\footnotetext{
${ }^{1}$ Private local small scale operators have in fact always been any where the public sector has not delivered and has had a particularly strong role in the poorest countries where service coverage in energy, water or transport offered by large public or private utilities is limited.

${ }^{2}$ As for many typologies, this one is arbitrary. There are obviously other possible factors such as the excess supply of funds on the international capital markets during the 1990s. But these are less directly related to the topic to be addressed by this paper.
} 
financing. The "privatization" dimension of the ideological revolution can thus be seen as one of the consequences of this fiscal crisis. ${ }^{3}$

Because competition has its limits in most network industries, the "privatization" component of the reforms transferred some monopolistic segments of the industry to private operators. ${ }^{4}$ This is the case for energy and water distribution and for their transmission or transportation. It is the case for regional monopolies in airports, ports and rail. In many countries, it is also the case for the local loop in telecoms. The existence of these private monopolies involved in the delivery of public services resulted in a de facto fourth mini-revolution during the 1990s. This revolution is in the internal organization of the residual public sector role in public services. Historically, self-regulation of the public monopolies had prevailed and generally produced few incentives for cost effective efficient service delivery. The reforms of the role of the government included a major change in the organization and implementation of regulation. This was intended, at least on paper, to address this incentive problem to contribute to the reduction in the financing requirements of the sector.

The debate on the regulation of the private monopolies has not been an easy one. It has centered on two main dimensions. The first was the extent to which countries needed to have independent regulatory agencies to reduce the risks of conflict of interest and of corruption in the regulation of the sector. This debate is important but beyond the scope of this paper. The second was the extent to which regulatory regimes could actually move toward efficiency oriented systems. More specifically, the debate was how to follow the lead of the United Kingdom and increase the incentives for efficiency for operators to promote cost reductions. These cost cuts would eventually be passed on to users through tariff reductions or to taxpayers through reductions in subsidy requirements.

The extent to which this efficiency dimension has been internalized by policymakers and academics in developing and transition economies is the main topic of this paper. The last 4-5 years have seen a small explosion of applied research on economic efficiency related issues in developing and transition economies. ${ }^{5}$ Many of the papers are quite useful at the policy level generating regulatory insights quite different from those gained from the analysis of regulatory outcomes in developed countries. Many have also proven that while the data problems are constraining, the constraints are not as binding as often argued.

The rest of the paper is organized as follows. Section 2 gives a quantitative sense of the spread and types of reforms that have taken place. Section 3 provides an overview of the research on efficiency measures in developing countries, including a discussion of the evidence on the efficiency effects of reform so-far. Section 4 discussed some of the alternatives to standard efficiency measures available to regulators. Section 5 concludes.

\footnotetext{
3 "Privatization" is an excessive word when it comes to public services. The actual sale of public assets to private operators has only been relatively common in some dimensions of the electricity generation, telecoms and the service component of the transport sector. In most other segments of the business, concession contracts, licences or leases have ensured the continuation of public property of the assets in the long run.

${ }^{4}$ Competition for the market helped in addressing the residual monopoly issues but not as much in developing countries as it did in developed economies. See Estache, Guasch and Trujllo (2003).

${ }^{5}$ There is also a significant literature on other efficiency concepts such as operating efficiency but these usually rely on partial performance indicators which are of limited use for economic analysis, in particularly in the context of regulatory or reform decisions. These are thus not covered in this paper.
} 


\section{Overview of the reforms}

Table 1 summarizes the results of a survey on the extent to which there is at least some corporate private sector participation in electricity distribution, telecoms, water \& sewerage, and railways across regions of the world. ${ }^{6}$ On average, a smaller proportion of the developing countries are sharing the responsibility for service delivery in these industries than in developed countries. In general also, it seems that among developing countries, the richest countries have been more systematic at engaging in reforms to attract the corporate private sector. ${ }^{7}$

Table 1: How present is the private sector in Network industries?

(Share of countries in total number of countries)

\begin{tabular}{|l|c|c|c|c|}
\hline & $\begin{array}{l}\text { Electricity } \\
\text { Distribution }\end{array}$ & $\begin{array}{l}\text { Water \& } \\
\text { Sewerage }\end{array}$ & Railways & Telecoms \\
\hline Developing Countries & $36 \%$ & $35 \%$ & $37 \%$ & $48 \%$ \\
\hline Developed countries & $43 \%$ & $80 \%$ & $65 \%$ & $83 \%$ \\
\hline \multicolumn{5}{|l|}{} \\
\hline Sub-Saharan Africa & $28 \%$ & $20 \%$ & $47 \%$ & $41 \%$ \\
\hline East Asia & $20 \%$ & $64 \%$ & $43 \%$ & $38 \%$ \\
\hline Eastern Europe & $48 \%$ & $62 \%$ & $20 \%$ & $58 \%$ \\
\hline Latin America & $61 \%$ & $41 \%$ & $56 \%$ & $67 \%$ \\
\hline Middle East & $6 \%$ & $18 \%$ & $20 \%$ & $23 \%$ \\
\hline South Asia & $13 \%$ & $13 \%$ & $50 \%$ \\
\hline
\end{tabular}

There is unfortunately no equivalent encompassing survey for the type of regulation used in reforming economies. There are however a few partial surveys which all point to an increased concern for the explicit consideration of efficiency in the choice of regulatory regimes. The largest survey is for a sample of about 1000 contracts in Latin America. ${ }^{8}$ The database contains detailed information on the characteristics of these concessions, including general details about the projects (sector, activity, year of award), the award criteria, size and duration of the concession, information with respect to the institutional context and degrees of freedom of the regulator, the type of regulatory framework put in place (price cap, rate of return, no regulation), and several details of the concession contract like arbitration clauses, nationality of operators, among others. In this rather encompassing data base, $56 \%$ of the contracts were regulated under a price cap regime, $20 \%$ under rate of return regulation. For $24 \%$ of the contracts, the regime is a hybrid one meaning that roughly $80 \%$ of the contracts signed in that region will require at some point some consideration of the efficiency gains achieved by the operators. Equivalent but smaller surveys for utilities were conducted in Africa and Eastern Europe. In all cases of water or electricity distribution covered by these surveys a price cap of some sort was adopted. Even if there may have been a selection bias in those surveys,

\footnotetext{
${ }^{6}$ More details in Estache and Goicoechea (2004).

${ }^{7}$ From now "private sector" is meant to mean "corporate private sector" since we ignore the role of small scale operators in the survey.

${ }^{8}$ For a full description, see Guasch (2003).
} 
their results tend to confirm the domination of incentive oriented regulation wherever a reform has taken place. ${ }^{9}$

The initial enthusiasm for the inclusion of efficiency in the design of regulation in developing countries is however being adjusted in developments observed over the last 23 years. The first development worth mentioning is that there is a significant slowdown in the presence of large volumes of private capital in the financing of infrastructure services in developing countries since the 1997 East Asia crisis. In many countries, the next generation of contracts seems to be moving toward management contracts or new designs of the 1970s performance contracts with heavy potential financing from donor agencies but with a stronger role for the private sector in the management and delivery. This means that the role of the regulators is likely to move from a focus of the efficiency on total expenditures to a focus on assessing separately the efficiency of operational and capital expenditures on a systematic basis because these activities may be subject to separate contracts. In many other countries, this means that the public sector will continue to be an important actor in the sector. This does not eliminate the concern for efficiency. In many countries this implies the adoption of corporatization strategies which all included an efficiency focus similar to one built-in in any collaboration with the private sector.

The second emerging development is a move away from pure forms of price or revenue cap toward more hybrid regimes. These regimes are hybrids because they include a clear focus on efficiency even if they often recognize that some of the cost categories will enjoy automatic or trigger driven pass-through to the users. This is most obvious in the renegotiation of contracts documented by Guasch (2004), but also in the initial design of contracts in electricity in Latin America for instance (Estache and Rossi (2004)). From the viewpoint of a regulator, this means that the coverage of the business over which regulatory decisions are based on mostly efficiency measures principally is a shrinking portion of the total. The specific share of the costs enjoying automatic passthrough varies across sectors but is largely dominated by activities subject to exchange risks (e.g. imported inputs and foreign debt service) or activities subject to negotiated long term arrangements (e.g. labor contracts). Efficiency gains are clearly continuing to be important for the other cost components. It could be argued that since the marginal effort on cost saving is likely to be concentrated on a narrower part of the cost structure, the relative importance of the efficiency measure is likely to increase.

The third evolution is the increased interest in national or international performance benchmarking in developing countries. The most obvious indicator is the number of regional associations of network regulators. The first one was for the regulators of energy of Latin America created in the late 1990s. Since then, equivalent associations are functioning for the water sector in Latin America and for all utilities in Africa, Eastern Europe, South Asia and since 2003 in East Asia. In all cases, there is an effort to generate consistent information across countries for the same sector. Progress is slow however, and international databases directly useful for standard economic efficiency measurement are not yet common-except for energy in Latin America and water and sewerage in Africa and in East Asia. In some countries as in Mexico or Peru in

\footnotetext{
${ }^{9}$ Estache and Goicoechea (2004).
} 
the port sector, the regulators have gone one step further in the benchmarking direction. They are working on the implementation of a formal system of yardstick competition between national ports but this is work in progress.

\section{Overview of the evidence on efficiency in developing and transition economies}

In spite of the sufficiently long experience with infrastructure reform in developing and transition economies, there is very little policy experience with the formal use of these measures in regulatory processes. Argentina, Brazil, Chile, Colombia, Mexico and Peru are the only six countries in which a formal assessment has actually been made as part of formal tariff revisions - to our knowledge. There is however a growing academic interest among the regulation specialists as well as among public sector specialists as discussed below. The interest is not concentrated in Latin America. The issue is also being discussed in various African and Asian countries including China, India, Ivory Coast, Kenya, Korea, Mali, Malaysia, Mauritania, Senegal and Uganda although not necessarily as part of formal tariff revisions. Moreover the survey shows that there are many regional benchmarking exercises covering Africa, Asia, the Caribbean or South America. The issue is also attracting a number of researchers in developing countries. The rest of this section provides a brief overview of the relevant literature for each subsector, distinguishing between utilities and transport. The distinction is done to reflect the real life sector separations in developing countries. In many countries indeed, when regulation takes place, the two main institutional models are: (i) a sector specific agency or (ii) a multisector agency. Increasingly, countries are adopting multisector agencies but they do so by bundling utilities and transport in separate agencies. ${ }^{10}$

\subsection{Utilities}

Utilities are usually defined as covering energy (excluding oil and gas production), water \& sewerage and telecoms. In this survey, we focus on the energy and water \& sewerage sectors because there is actually very little literature on the measurement of efficiency in the telecommunications sector in developing countries. ${ }^{11}$ Most of the literature focuses on partial performance indicators and uses standard econometric techniques to explain those indicators. ${ }^{12}$ There is also an important literature relying on cost proxy models, initially developed for the US telecoms, to assess efficiency and

\footnotetext{
${ }^{10}$ Interestingly enough, in most countries, the telecom sector usually enjoys its own regulator. This is usually the result of the fact that telecoms were the first to be reformed and the creation of an agency was often part of the reform package.

${ }^{11}$ Interesting exception are Das (2000) who use of translog cost function to argue for the need to arbitrate between loss of scale and scope economies and competition in further restructuring of the Indian telecoms and Facanha and Resende (2004) who makes the case for quality adjusted performance indicators, Resende and Facanha (2004) who make the case for yardstick competition in the sector in Brazil and Colson and Mbangala (2003) who assess the effects of reforms in Africa's telecoms sector during the 1990s.

12 Gutierrez (2003) offers a very readable survey of the literature.
} 
address other regulatory issues. ${ }^{13}$ But both of these areas go beyond the scope of this paper and are hence not reviewed here.

\subsubsection{Energy}

The literature on this sector is growing fast but it has many common features. We identified almost 30 papers, reported in Table 2, covering full systems, generation only or distribution only. Most of the papers are on the electricity sector. Only two deal with the gas sector in developing or transition economies and both are on Argentina, the only country in which a tariff revision including a discussion of the revision of the cap actually took place. ${ }^{14}$

Most papers focus on a single output. In most cases, they focus on the production side of the business but cost data are much more difficult to obtain. DEA is the most common approach. There is an unusually large number of papers relying on both nonparametric and parametric approaches to check the robustness of the results or of the policy conclusions.

Most of them (over $50 \%$ of the papers) rely on country specific data. This is because in many countries, the reforms have created many business units which can be compared with each other. Among developing countries, Latin America is the most studied region, reflecting the payoff of the efforts made by the Latin American Association of Energy Regulators to generate comparable data.

In general, when authors focus on the cost side of the business, the main difference across papers comes from the differences of the expenditure type they focus on: operational, capital expenditures or total expenditures. The papers focusing on the production side deal with either the number of clients served or total energy sold. Since in many countries the operators tend to control more the energy supplied than the number of customers--in general operators are subject to connection obligations, not necessarily to service obligations at any tariff-- the most common proxy for output is energy sold.

As in all other sectors, the choice on the input side is generally driven as much by data availability as it is by economic principles. The number of employees is the standard labor input and is easily obtained. For the capital inputs, however, the options are more difficult. Transformer capacity is widely accepted as a required variable. Many authors also consider kilometers of distribution lines, which measure (with some approximation) the amount of network capital. There is however a recognition that it can reflect geographical dispersion of consumers as much as differences in productive efficiency. The main lesson is that network capital can thus be treated as an output or as an input but it is necessary to control for geographical dispersion. Generally, with a single equation production frontier, it is treated as an input. ${ }^{15}$ As suggested by Kumbhakar and

\footnotetext{
13 The conceptual framework is presented in the book by Gasmi et al. (2002) and their 2000 article. An illustration for Argentina is provided in Benitez et al (2001).

14 This section is to a large extent a major update of the papers reviewed in Jamasb and Pollitt (2001).

${ }^{15}$ Since physical measures of capital (as the ones used in this study) cannot capture all the capital equipment used in the production process (aside of the difficulties to account for differences in asset quality, age and composition), an alternative is to represent all capital in a single monetary measure. However, creating monetary measures of capital is problematic because accounting methods and revaluation policies are not uniform within organizations. Furthermore, there is still debate over the correct method of calculating the monetary value of capital.
} 
Hjalmarsson (1998), there are many instances in which it makes sense to focus on labor productivity only, rather than to rely on methods which make implicit assumptions on the joint evolution of factor efficiency and this is being increasingly recognized in the recent literature.

Regarding the environmental variables included in the models, service area is an exogenous (scale) operating characteristic of the firm's environment. When the number and type of customers served can be assumed to be exogenous, it is often also included as a control variable of some sort - often customer density to get to the demographics impacting the sector; the higher the density the higher the productivity. Differences in voltages required by customers may matter and hence the need to model the share of residential vs. non-residential users. On the quality side, it is not unusual for researchers to include a variable representing the security of supply, peak-load demand, technical losses and outages. Finally, cross-country papers also include GNP per capita to control for differences in the socio-economic environment in which firms operate in each country.

An interesting additional feature of this literature is the willingness of some authors to rely on 2-stage processes to assess the impact of the institutional or policy variables. These authors compute the efficiency scores in a first stage. They then rely, in a second stage, on a regression to explain these scores with various types of variables. The econometric models used vary from simple OLS to Tobit or Probit models.

The large set of papers available and their diversity provide a set of useful lessons. The main one may be that there is a clear interest in benchmarking performance in the sector. Benchmarking can be done to simply generate performance rankings. This was common in the first multi-country studies (Whiteman $(1995,1998)$ or Pollitt (1995)) and continues to be a popular use of the methods including at the country level (Lavado (2004) for the Philippines). Benchmarking can also be done to generate a sense of the scope for tariff reductions in the case of specific tariff revision as is the case for the papers on Argentina, Brazil, Chile, Colombia and Peru where consulting firms of more academic regulators have worked on generating efficiency measures. Finally, benchmarking can be used to promote some form of yardstick competition within countries or across countries as argued by Domah (2004), Estache, Rossi and Ruzzier (2004) or Resende (2002). In general, the publications tell a fairly powerful story. For Latin America, for instance, the efficiency gains achieved are of the order of $5-7 \%$ per year. This is not negligible and significantly higher than what was estimated for the gas sector in Argentina for instance.

These benchmarking studies generate a number of other useful results. First, Pollitt (1995) relying on both parametric and DEA techniques as well as second-stage regression to use institutional variables to explain differences in efficiency scores for each segment of the electricity systems as well as the full systems suggests that there were no significant differences for LDCs from the average of other countries in the early part of the 1990s. These results have been globally confirmed by Whiteman $(1995,1998)$. Relying on a larger set of countries, he finds that efficiency levels in developing countries were very roughly equivalent to those in Australia and Japan, the United States or lower than in Europe but much higher than in Canada or the Asian Tiger economies-Hong Kong, South Korea, Singapore and Taiwan. He also finds that the "baby tigers"- 
Thailand, the Philippines, Malaysia and Indonesia-were average performers as well. Note that the specific rankings vary with the methodology used (DEA vs. SPF).

Second, these studies also provide some sense of the major environmental variables to consider as part of the reform agenda. Pollitt (1995) was quite careful at correcting for environmental variables in his detailed study of segments of the sector. Lam and Shiu (2004) focusing on the generation side of the business test in a second-stage regression the relevance of institutional variables as well as capacity, size and age variables for the capital inputs and the quality and availability of fuel. They find that autonomy, location and coal endowment all contribute to the good ranking of an operator. They also find that these factors can be sufficient to offset the negative effects of a lack of size of an operator. Melo and Espinoza (2004) find that higher population density improves efficiency scores.

Third many of the authors find that size matters to both generation and distribution. Yumos and Hawdon (1997) were the first to suggest that scale is an issue in the sector in all countries from cross-country evidence which included developing economies. Meibodi (1998) finds a similar result for Iran and Pacudan and de Guzman (2002) for the Philippines. These results are also confirmed by Filippini et al (2004) for a transition economy. They go further in using their results to argue that reformers should consider promoting the merger of the smaller distribution utilities in Slovenia.

Fourth, the literature also provides a sense of the actual importance of the much debated role of ownership and regulation in the sector. In general, the impression is that privatization has been associated with improvements in efficiency but only with or through other reforms. Bagdadioglu et at. (1996) may have the most positive result and show that private distributors have better technical and scale efficiency on average. They do however also show that some public operators have scores equivalent to those observed for private operators. Yumos and Hawdon (1997) find ownership change is only useful to improve efficiency with increases in competition. Estache and Rossi (2004) complement this result for distribution companies in Latin America. They show that privatization is not the important variable but regulation is. Productivity increases with degree of incentives built in regulation but privatized firms under rate of return have at most similar labor productivity as public firms. Similar results are obtained by Pombo and Ramirez (2002 and 2004) for Colombia). In a rare African case study, Plane (1997) assesses for Cote d'Ivoire the impact of the privatization of management with no labor dismissal allowed on technical efficiency and the distribution of the effects among users and owners. He shows that efficiency improved but irregularly and was never as efficient as when under public management and tight budget constraint. The users did benefit from lower prices and quality improvements. Motta (2004) complements the assessment by showing for Brazil that privatization had no statistically significant impact on technical efficiency when using OPEX as an input but resulted in a strong drop in technical efficiency when considering total expenditures. There is some uncertainty on the economic meaning of the result since it may reflect a surge in investment or a substitution between capital and labor post privatization. Berg et al (2004) show in the case of Ukraine that privatization can be good but bad regulation can lead to perverse incentives and deteriorate efficiency scores. Cost plus regulation has been used more effectively by 
private operators to increase shareholder value through cost inflation which has been passed on to users through higher tariffs.

Finally, many of the papers on Latin and South America have shown that it may be useful to try to distinguish between technological and efficiency changes. One of the main results in this context is that reforms contribute to improve both of these efficiency sources. The two studies by Pombo and Ramirez $(2002,2004)$ on Colombia are particularly well documented on this point.

Table 2: Energy

\begin{tabular}{|c|c|c|c|c|}
\hline Region & Data & Reference & Method & Policy relevance \\
\hline World & $\begin{array}{l}768 \text { thermal power plants } \\
\text { operating in } 14 \text { countries, } \\
\text { including South Africa and } \\
\text { Thailand } \\
1989\end{array}$ & Pollitt (1995) & $\begin{array}{l}\text { SCF/DEA } \\
\text { with } 2^{\text {nd }} \text { stage } \\
\text { regressions } \\
\text { Tobit }\end{array}$ & $\begin{array}{l}\text { Finds that privatization does not lower costs in the short } \\
\text { run for the industry once allowance was made for } \\
\text { ownership, load or country. Government interference } \\
\text { with investment decisions do however increase costs. }\end{array}$ \\
\hline World & $\begin{array}{l}111 \text { electricity generation systems } \\
1989-1995 \text { (unbalanced panel) }\end{array}$ & Whiteman (1998) & DEA/SFP & $\begin{array}{l}\text { Finds that levels in developing countries were very } \\
\text { roughly equivalent to those in Australia, Japan, the US } \\
\text { or lower than in Europe but much higher than in Canada } \\
\text { or the Asian Tiger economies (specific ranking driven } \\
\text { by method). }\end{array}$ \\
\hline World & $\begin{array}{l}32 \text { companies from } \text { Austria, } \\
\text { Netherlands, UK and } 1 \\
\text { Argentinean }\end{array}$ & $\begin{array}{l}\text { Frontier } \\
\text { Economics and } \\
\text { Macroconsulting } \\
(2001)\end{array}$ & DEA & $\begin{array}{l}\text { Consultant report prepared for the regulator to } \\
\text { benchmark the performance of one Argentinean } \\
\text { distribution company in preparation for its price review. }\end{array}$ \\
\hline LDCs & 85 electricity systems & Whiteman (1995) & DEA & Benchmarking exercise. \\
\hline LDCs & $\begin{array}{l}\text { 1. Cross-section of generation for } \\
27 \text { countries in } 1987 \\
\text { 2. Panel of electricity generating } \\
\text { utilities from Malaysia, Thailand } \\
\text { and the UK for 1975-1990 period }\end{array}$ & $\begin{array}{l}\text { Yumos and } \\
\text { Hawdon (1997) }\end{array}$ & DEA & $\begin{array}{l}\text { Points to major efficiency gaps between small scale and } \\
\text { large providers; also finds that changes in ownership do } \\
\text { not resolve efficiency problems automatically when } \\
\text { there is no competition. }\end{array}$ \\
\hline $\begin{array}{l}\text { South } \\
\text { America }\end{array}$ & $\begin{array}{l}30 \text { South American Distribution } \\
\text { companies from } 10 \text { countries } \\
\text { 1994-1998 }\end{array}$ & $\begin{array}{l}\text { Rodriguez- } \\
\text { Pardina, Rossi and } \\
\text { Ruzzier (1998) }\end{array}$ & SPF & $\begin{array}{l}\text { Assessment of average efficiency levels and growth } \\
\text { rates. }\end{array}$ \\
\hline $\begin{array}{l}\text { South } \\
\text { America }\end{array}$ & $\begin{array}{l}36 \text { South American Distribution } \\
\text { companies from } 10 \text { countries } \\
1994-1998\end{array}$ & $\begin{array}{l}\text { Rodriguez-Pardina } \\
\text { and Rossi (2000) }\end{array}$ & SPF/DEA & $\begin{array}{l}\text { Separation of catching up and technological change } \\
\text { effect. }\end{array}$ \\
\hline $\begin{array}{l}\text { Latin } \\
\text { America }\end{array}$ & $\begin{array}{l}84 \text { Latin American Distribution } \\
\text { companies } \\
1994-2001\end{array}$ & $\begin{array}{l}\text { Estache, Rossi and } \\
\text { Ruzzier (2004) }\end{array}$ & $\begin{array}{l}\mathrm{SCF} / \mathrm{DEA} / \\
\text { labor } \\
\text { requirement } \\
\text { function }\end{array}$ & $\begin{array}{l}\text { Makes the case for an international yardstick } \\
\text { competition regulatory regime and discusses and } \\
\text { illustrates the implementation challenges in the context } \\
\text { of Latin America. }\end{array}$ \\
\hline $\begin{array}{l}\text { Latin } \\
\text { America }\end{array}$ & $\begin{array}{l}\text { Panel of } 127 \text { Latin American } \\
\text { Distribution companies } \\
\text { 1994-2001 }\end{array}$ & $\begin{array}{l}\text { Estache and Rossi } \\
\text { (2004) }\end{array}$ & $\begin{array}{l}\text { Labor } \\
\text { requirement } \\
\text { function/SPF }\end{array}$ & $\begin{array}{l}\text { Shows that productivity increases with degree of } \\
\text { incentives built in regulation. Private under rate of return } \\
\text { have at most similar labor productivity as public firms. }\end{array}$ \\
\hline $\begin{array}{l}\text { Small } \\
\text { Island } \\
\text { Economies }\end{array}$ & $\begin{array}{l}\text { Panel data of } \text { generation } \\
\text { companies for } 16 \text { small island } \\
\text { economies vs. } 121 \text { investors } \\
\text { owned US generators } \\
1993-2000\end{array}$ & Domah (2002) & $\begin{array}{l}\mathrm{DEA} / \mathrm{SPF} \\
\text { with } 2^{\text {nd }} \text { stage } \\
\text { regressions }\end{array}$ & $\begin{array}{l}\text { Shows that use of non-small islands in benchmarking is } \\
\text { feasible and desirable. } \\
\text { Interconnection influences efficiency scores and changes } \\
\text { performance incentives. }\end{array}$ \\
\hline Argentina & $\begin{array}{l}\text { Panel of } 8 \text { gas Argentinean } \\
\text { distribution companies } \\
\text { 1970-1995 }\end{array}$ & NERA (1997) & TFP & $\begin{array}{l}\text { Estimate that using customers are proxy for output, } \\
\text { annual } X \text { to be used in tariff revision should be around } \\
2.4 \% \text {. }\end{array}$ \\
\hline Argentina & $\begin{array}{l}\text { Panel of } 8 \text { gas Argentinean } \\
\text { distribution companies } \\
\text { 1993-1997 }\end{array}$ & Rossi (2001) & SPF & $\begin{array}{l}\text { Major catching up and frontier shift during the period } \\
\text { for all operators. }\end{array}$ \\
\hline Brazil & $\begin{array}{l}\text { Cross-section of } 24 \text { distribution } \\
\text { operators } \\
1997 / 1998 \text { data }\end{array}$ & Resende (2002) & DEA & $\begin{array}{l}\text { Argues for relative efficiency scores in the design of a } \\
\text { national yardstick competition regulatory regime in } \\
\text { Brazil. }\end{array}$ \\
\hline
\end{tabular}




\begin{tabular}{|c|c|c|c|c|}
\hline Brazil & $\begin{array}{l}\text { A report for each of the } 64 \\
\text { distribution operators under } \\
\text { ANEEL supervision } \\
2003\end{array}$ & $\begin{array}{l}\text { Brazilian } \\
\text { Regulatory } \\
\text { Agency (ANEEL) } \\
(2004)\end{array}$ & $\begin{array}{l}\text { TFP and basic } \\
\text { performance } \\
\text { benchmarking }\end{array}$ & $\begin{array}{l}\text { Each operator generated a report explaining how they } \\
\text { assessed all variables and how they estimated efficiency } \\
\text { gains and subjected it to assessment of regulator. }\end{array}$ \\
\hline Brazil & $\begin{array}{l}\text { Distribution companies } \\
1994 \text { and } 2000\end{array}$ & Motta (2004) & $\mathrm{DEA} / \mathrm{SPF}$ & $\begin{array}{l}\text { Privatisation has no statistically significant impact with } \\
\text { OPEX as input but results in strong drop in technical } \\
\text { efficiency when considering Total expenditures. } \\
\text { May reflect surge in investment or substitution between } \\
\text { capital and labor. } \\
\text { Makes case for inclusion of capital costs in any } \\
\text { benchmarking exercise. }\end{array}$ \\
\hline Chile & 35 empresas de distribucion & $\begin{array}{l}\text { Sanhueza and } \\
\text { Rudnick (2004) }\end{array}$ & DEA & $\begin{array}{l}\text { Relies on DEA Efficiency measure to assess the } \\
\text { electricity distribution value added. }\end{array}$ \\
\hline Chile & 35 empresas de distribucion & $\begin{array}{l}\text { Sanhueza and } \\
\text { Rudnick (2003) }\end{array}$ & $\mathrm{DEA} / \mathrm{SPF}$ & $\begin{array}{l}\text { Analyses levels and sources of differences across } \\
\text { operators. } \\
\text { Shows novel use of bootstrapping techniques to asses } \\
\text { each operator's efficiency. }\end{array}$ \\
\hline China & $\begin{array}{l}\text { Panel of } 30 \text { municipal }, \\
\text { autonomous } \\
\begin{array}{l}\text { regions and } \\
\text { provincial thermal generation } \\
\text { plants }\end{array} \\
1995-2000\end{array}$ & $\begin{array}{l}\text { Lam and Shiu } \\
\text { (2004) }\end{array}$ & $\begin{array}{l}\text { DEA with } 2^{\text {nd }} \\
\text { stage } \\
\text { regression }\end{array}$ & $\begin{array}{l}\text { Shows that average annual TFP growth rate was } \\
2 . \% / \text { year on average. } \\
\text { Confirm earlier results on relevance of location. } \\
\text { Fuel efficiency and capacity also mattered. }\end{array}$ \\
\hline China & $\begin{array}{l}\text { Panel of } 30 \quad \text { municipal, } \\
\text { autonomous }\end{array}$ & $\begin{array}{l}\text { Lam and Shiu } \\
\text { (2001) }\end{array}$ & $\begin{array}{l}\text { DEA with } 2^{\text {nd }} \\
\text { stage } \\
\text { regression }\end{array}$ & $\begin{array}{l}\text { Find that location (coastal vs. interior), coal endowment, } \\
\text { fuel efficiency, capacity and autonomy from the central } \\
\text { government, are important determinants of efficiency. } \\
\text { Find no evidence of excess capacity. Find no evidence } \\
\text { of relevance of FDI. Point to labour redundancy issue. }\end{array}$ \\
\hline Colombia & $\begin{array}{l}\text { Panel of } 33 \text { distribution } \\
\text { companies }\end{array}$ & $\begin{array}{l}\text { Pombo and } \\
\text { Ramirez (2002) }\end{array}$ & $\begin{array}{l}\text { DEA with } 2^{\text {nd }} \\
\text { stage } \\
\text { regression }\end{array}$ & $\begin{array}{l}\text { Shows that the reforms of the } 1990 \text { s improved the } \\
\text { average efficiency levels of the sector; regulatory policy } \\
\text { had positive effect but ownership has no conclusive role. }\end{array}$ \\
\hline Colombia & $\begin{array}{l}\text { Panel of } 18 \text { distribution operators } \\
2000-2001\end{array}$ & $\begin{array}{l}\text { Columbian } \\
\text { Regulatory } \\
\text { Agency (CREG) } \\
(2002)\end{array}$ & DEA & $\begin{array}{l}\text { Meaured for each operator the efficiency gains to be } \\
\text { used in assessment of authorized transmission tariff for } \\
2003-2007 \text { period }(1.63 \%-2.51 \% \text { depending on tension } \\
\text { level). }\end{array}$ \\
\hline Colombia & $\begin{array}{l}\text { Panel of } 20 \text { distribution } \\
\text { companies } \\
\text { 1999-2003 }\end{array}$ & $\begin{array}{l}\text { Melo and Espinoza } \\
\text { (2004) }\end{array}$ & DF-P & $\begin{array}{l}\text { No significant changes during the period covered; } \\
\text { environmental variables matter significantly - the higher } \\
\text { the population density, the higher the efficiency. }\end{array}$ \\
\hline Colombia & $\begin{array}{l}\text { Panel of } 33 \text { generation and } 12 \\
\text { distribution companies } \\
1988-2000\end{array}$ & $\begin{array}{l}\text { Pombo and } \\
\text { Ramirez (2002) }\end{array}$ & $\begin{array}{l}\text { DEA with } 2^{\text {nd }} \\
\text { stage } \\
\text { regression }\end{array}$ & $\begin{array}{l}\text { Shows that the reforms of the } 1990 \text { s improved the } \\
\text { average efficiency levels of the sector. Technology } \\
\text { improvements and regulatory policy had positive effect } \\
\text { but wedge between good and bad performers increased. }\end{array}$ \\
\hline Iran & $\begin{array}{l}\text { Benchmarks Iranian companies } \\
\text { with LDC sample }\end{array}$ & Meibodi (1998) & $\mathrm{DEA} / \mathrm{SPF}$ & $\begin{array}{l}\text { A large share of differences in efficiency can be } \\
\text { explained by plant size. }\end{array}$ \\
\hline Ivory Coast & $\begin{array}{l}\text { Time-series } \\
1959-1995\end{array}$ & Plane (1999) & SPF & $\begin{array}{l}\text { Finds significant but irregular efficiency gains from the } \\
\text { privatization of management. In addition finds that users } \\
\text { gained through lower tariffs from efficiency gains. }\end{array}$ \\
\hline Peru & $\begin{array}{l}\text { Panel of } 19 \text { distribution operators } \\
1995-1998\end{array}$ & $\begin{array}{l}\text { Bonifaz and Santin } \\
\text { (2000) }\end{array}$ & $\begin{array}{l}\text { DEA with } 2^{\text {nd }} \\
\text { stage } \\
\text { regressions }\end{array}$ & $\begin{array}{l}\text { Relative efficiency assessment for the Peruvian } \\
\text { Distribution operators. }\end{array}$ \\
\hline Philippines & $\begin{array}{l}146 \text { electricity distribution } \\
\text { operators } \\
1998\end{array}$ & $\begin{array}{l}\text { Pacudan and de } \\
\text { Guzman (2002) }\end{array}$ & DEA & $\begin{array}{l}\text { Used to simulate effects of energy efficiency policy } \\
\text { measures on productive efficiency. } \\
\text { Highlight the importance of scale efficiency. }\end{array}$ \\
\hline Philippines & 119 electricity cooperatives & Lavado (2004) & $\mathrm{DEA} / \mathrm{SCF}$ & $\begin{array}{l}\text { Ranking of operators. } \\
\text { Estimates annual TFP growth at } 1.7 \% \text {, explained evenly } \\
\text { by a frontier shift and catching up. }\end{array}$ \\
\hline Slovenia & $\begin{array}{l}\text { Panel of } 5 \text { Slovenian electricity } \\
\text { distribution firms } \\
1991-2000\end{array}$ & $\begin{array}{l}\text { Filippini, Hrovatin } \\
\text { and Zoric (2004) }\end{array}$ & $\mathrm{SCF}$ & $\begin{array}{l}\text { Paper makes a case for merger of excessive number of } \\
\text { small scale operators. }\end{array}$ \\
\hline Turkey & Cross section of 70 Turkish & Bagdadioglu, Price & DEA & Shows that private distributors have better technical and \\
\hline
\end{tabular}




\begin{tabular}{|l|l|l|l|l|}
\hline & $\begin{array}{l}\text { electricity distribution operators } \\
1991\end{array}$ & $\begin{array}{l}\text { and Weyman- } \\
\text { Jones (1996) }\end{array}$ & $\begin{array}{l}\text { scale efficiency on average but some public operators } \\
\text { have equivalent scores. }\end{array}$ \\
\hline Ukraine & $\begin{array}{l}24 \quad \text { Ukrainian electricity } \\
\text { distribution companies } \\
1998-2002\end{array}$ & $\begin{array}{l}\text { Berg, Lin and } \\
\text { Tsaplin (2004) }\end{array}$ & SPF/DEA & $\begin{array}{l}\text { Shows that private operators respond more aggressively } \\
\text { to incentives than do public operators. When regulation } \\
\text { has perverse incentives efficiency worsens. }\end{array}$ \\
\hline
\end{tabular}

(*) SPF: Stochastic Production Frontier; SCF Stochastic Cost Frontier; DF: Distance Function ( $\mathrm{P}=$ production, $\mathrm{C}=$ Cost); DEA: Data Envelopment Analysis.

\subsubsection{Water and Sewerage}

While the share of contracts signed with private operators and regulated under some type of incentive based regime is about as high as it is for the energy sector in developing and transition economies, somewhat surprisingly the number of studies covering the sector is quite limited. We found 8 studies, of which only 4 are actually published and 3 more have actually been issued as working papers by an academic or official institutions. The last one is a mimeo. Table 2 shows that half the papers rely on parametric techniques, 3 on DEA and 1 on an index number. Most studies focus on the production side. Volume of water produced or sold and volume of sewerage collected or number of connections tend to be the most common output variables. A few focus on the cost side and then the issue is on what cost to focus on (operational, capital or total?).

Table 3: Water and Sewerage

\begin{tabular}{|c|c|c|c|c|}
\hline Region & Data & Reference & Method (*) & Policy relevance \\
\hline Africa & $\begin{array}{l}21 \text { African water utilities, } \\
\text { including } 3 \text { private } \\
1995-1997\end{array}$ & $\begin{array}{l}\text { Estache and } \\
\text { Kouassi (2002) }\end{array}$ & $\begin{array}{l}\text { SPF and } 2^{\text {nd }} \\
\text { stage Tobit } \\
\text { model }\end{array}$ & $\begin{array}{l}\text { Find that private operators are more cost- } \\
\text { efficient and that corruption worsens efficiency; } \\
\text { also show that corruption matters much more } \\
\text { than ownership. }\end{array}$ \\
\hline Africa & $\begin{array}{l}110 \text { African water utilities } \\
\text { 1998-2001, including } 14 \\
\text { private }\end{array}$ & $\begin{array}{l}\text { Kirkpatrick, } \\
\text { Parker, and } \\
\text { Zhang (2004) }\end{array}$ & $\begin{array}{l}\text { SCF/DEA with } \\
2^{\text {nd }} \text { stage } \\
\text { regressions }\end{array}$ & $\begin{array}{l}\text { Finds no significant difference between public } \\
\text { and private operators in terms of cost once } \\
\text { environmental factors have been accounted for. } \\
\text { Regulation has no significant impact either. }\end{array}$ \\
\hline Asia & $\begin{array}{l}50 \text { firms in } 19 \text { countries } \\
1997\end{array}$ & $\begin{array}{l}\text { Estache and } \\
\text { Rossi (2002) }\end{array}$ & SCF & $\begin{array}{l}\text { Find no statistically significant difference } \\
\text { between public and private operators in the } \\
\text { sector. }\end{array}$ \\
\hline Argentina & $\begin{array}{l}4 \text { provinces } \\
\text { 1992-2001 (unbalanced } \\
\text { panel) }\end{array}$ & $\begin{array}{l}\text { Estache and } \\
\text { Trujillo (2003) }\end{array}$ & TFP & $\begin{array}{l}\text { Find a significant improvement resulting from } \\
\text { the } 1990 \text { s reforms in the sector. } \\
\text { Also shows that one of the renationalized } \\
\text { companies is managing to maintain private } \\
\text { gains. } \\
\text { Show that ignoring the multiproduction nature of } \\
\text { the operators business (water + sewerage) leads } \\
\text { to misleading policy conclusion on the } \\
\text { performance of operators. }\end{array}$ \\
\hline Brazil & $\begin{array}{l}20 \text { state operators } \\
1996-2000\end{array}$ & $\begin{array}{l}\text { Tupper and } \\
\text { Resende (2004) }\end{array}$ & $\begin{array}{l}\text { DEA with } 2^{\text {nd }} \\
\text { stage Tobit }\end{array}$ & $\begin{array}{l}\text { Ranking of operators. } \\
\text { Makes the case for yardstick competition. }\end{array}$ \\
\hline Brazil & $\begin{array}{l}\text { Around } 4000 \text { (depending } \\
\text { on the year) municipalities } \\
\text { of Brazil } \\
1996-2002\end{array}$ & $\begin{array}{l}\text { Seroa da Motta } \\
\text { and Moreira } \\
(2004)\end{array}$ & $\begin{array}{l}\text { DEA with } 2^{\text {nd }} \\
\text { stage regression }\end{array}$ & $\begin{array}{l}\text { Private operators stimulate catching up but there } \\
\text { is no significant difference between public and } \\
\text { private operators in terms of the total variation in } \\
\text { productivity. Regional operators benefit from } \\
\text { scale economies but have the lowest productivity } \\
\text { levels. Municipalities have the highest } \\
\text { productivity levels. }\end{array}$ \\
\hline Peru & $\begin{array}{l}43 \text { operators } \\
1996-1998\end{array}$ & Corton (2003) & $\mathrm{SCF}$ & $\begin{array}{l}\text { Cost models which accounts for location, } \\
\text { dispersion, size in production and size in } \\
\text { administrative responsibility (number of districts }\end{array}$ \\
\hline
\end{tabular}




\begin{tabular}{|l|l|l|l|l|}
\hline & & & & $\begin{array}{l}\text { covered). These factors account for 90\% of } \\
\text { differences in costs. } \\
\text { Makes a cost based case for mergers of some of } \\
\text { the companies. } \\
\text { Documents lack of incentives of operators. }\end{array}$ \\
\hline Peru & $\begin{array}{l}45 \text { operators } \\
1998-2000\end{array}$ & $\begin{array}{l}\text { Alva and } \\
\text { Bonifaz (2001) }\end{array}$ & $\begin{array}{l}\text { DEA with } 2^{\text {nd }} \\
\text { stage regression } \\
\text { analysis of } \\
\text { efficiency } \\
\text { measure }\end{array}$ & $\begin{array}{l}\text { Ranking of operators for a 3 years period. } \\
\text { Find returns to scale. } \\
\text { Find important role for environmental variables. }\end{array}$ \\
\hline
\end{tabular}

(*) SPF: Stochastic Production Frontier; SCF Stochastic Cost FrontierDEA: Data Envelopment Analysis; TFP: Total factor productivity index number;

For the papers focusing on cost, labor cost, other input costs, production levels, number of clients, population density, water sources (e.g. surface, ground,...), and quality variables tend to be standard. Increasingly also, analysts add environmental variables, including institutional characteristics. Note that these models are sometimes run with quadratic forms to get non-linearities in the technology, including possible returns to scale. For the papers focusing on the production side of the business, employment, fuel and other energy consumption, network size and other expenses are the most common found. The specific functional forms and variable choices are of course driven by data availability.

There are few overall policy lessons from these few studies but those emerging from a comparison of experiences across regions and countries are important. Probably the most important lesson is that the econometric evidence on the relevance of ownership suggests that in general, there is no statistically significant difference between the efficiency performance of public and private operators in this sector. The only paper on Asia (Estache and Rossi (2002) and the paper using the latest data on Africa (Parker and Saal (2004) are both quite robust at that level. An earlier econometric study on the efficiency of the African companies found, with a much smaller sample, some superiority for private operators but the efficiency effect of ownership was much lower than the effect of good governance in the sector. This mixed review of the efficiency payoff of private sector participation may have to be correlated with the observation that water is the sector with the highest rate of renegotiation. According to Guasch (2004), 75\% of the water contracts signed in Latin America during the 1990s were renegotiated.

The story is however not that simple. Indeed, the first published country specific paper on this issue in this sector shows the high efficiency payoffs of the privatization policy for 4 Argentinean provinces based on the calculation of a Malmquist index (Estache and Trujillo (2003)). Annual efficiency gains vary from $2.3 \%$ for the largest concession to $13.5 \%$ for one of the smaller ones. Note that the first average is over an 8 year period and the second over a 3 year period. The difference is at least partially explained by the fact that the biggest bang for the buck of privatization in these industries is immediately after the reform since the operators know that they will eventually have to share with the users the efficiency gains as part of a scheduled tariff revision. This is in fact illustrated by Seroa da Motta and Moreira (2004) in their recent working paper when they document that private operators stimulate a quick catching up but don't get associated to frontier shifts more than public operators in this sector in Brazil.

The second lesson to emerge is that there is a clear case for increased yardstick competition in the sector, independently of whether the private sector plays a crucial 
role.. Tupper and Resende (2004) provide a very pragmatic illustration of how this could work out in a large country, adapting Bogetoft (1997 and 2000). The various papers on Peru may not be as precise in making the case but the efficiency measures used to rank operators could easily be built in the Tupper-Resende model. Similarly, the various papers on Africa provide the raw material to design a yardstick competition system across sufficiently similar countries within a region.

Third, various papers document the importance of accounting for environmental variables in this sector. The papers on Peru for instance, in particular Corton (2003), are extremely careful at assessing the relevance of a range of variables which are not under the control of the regulated operators. Location, population dispersion, and number of municipalities in the area of responsibility all contribute significantly to differences in performance across operators.

Fourth, it is quite important to recognize that operators are in practice involved in a multiproduct operation. Most provide water but also generally collect sewage. Estache and Trujillo (2003) show that ignoring the multiproduct nature of the business in Argentina would have resulted in an overestimation of the efficiency gains achieved since reforms. For the operators for which the data were available, the estimated annual average efficiency gains dropped from $4.2 \%$ to $2.6 \%$.

Finally, the size issue and the concern for scale economies is a recurring theme. The various African studies all recognize that the samples used do not do justice to the large role played by small-scale operators. There is however not enough data available to make a fair assessment of the interface between small and large actors in the sector. Corton (2004) has enough data to show that in the Peruvian context, it could make sense to promote some mergers in view of the room available for scope and scale economies in the sector in that country.

\subsection{Transport}

The demand for efficiency studies in transport comes about differently than for utilities. Transport operators tend to face much more competition than most of the utilities operators. There is thus apparently a lesser role for regulation in this sector. This is probably true for most inland transportation and most obviously passenger transport where the variety of modes provides enough options to choose from. For freight, the situation is more complex. The competition between trucks and railways is generally strong enough for inland transport even if in railways there are regulatory issues related to captive shippers and access rules--but these are relatively easy to address. Competition is however not as effective in the port sector. Indeed, it is increasingly clear that many of the efficiency gains achieved from inland transport competition and railways reforms get wasted in the port sector. ${ }^{16}$ In a recent paper, Clark et al. (2004) show that improving relatively marginally port efficiency could reduce shipping costs by about $12 \%$. From the viewpoint of transport regulators it is thus quite important to get a sense of the potential cost savings that could be achieved. The remainder of this section reveals a surprising low interest of policymakers and researchers in addressing this issue for developing

\footnotetext{
${ }^{16}$ See for instance the discussion in the European context in Gonzalez, Tovar and Trujillo (2004).
} 
countries. There are indeed very few policy relevant quantitative papers on economic efficiency on either ports or railways.

\subsubsection{Ports}

Ignoring the large literature on partial performance indicators in the sector, the academic coverage of economic efficiency in the port sector is quite scarce indeed in the world in general. Focusing on developing countries reduces the number to 8 articles as seen in Table 4. The main interests of these studies vary significantly across these few papers. They go from an attempt to establish a link between ownership and efficiency to the generation of rankings for benchmarking purposes or to estimates of the efficiency gains to be used as part of a tariff revision. Some of the studies tend to be cross-country and those often cover both Asian and European countries as benchmarks. Others focus on specific countries such as India, Korea or Mexico. Somewhat surprising it is often difficult to know exactly what is being measured. Few of the studies are in indeed specific as to which part of the port sector they are focusing on. Based on the data used, it seems that the most common output measured is cargo handling services.

Table 4: Ports

\begin{tabular}{|c|c|c|c|c|}
\hline Region & Data & Reference & Method (*) & Policy relevance \\
\hline World & $\begin{array}{l}\text { Panel of } 25 \\
\text { countries } \\
\text { (including } 3 \\
\text { developing } \\
\text { countries) } \\
\text { 1992-1999 }\end{array}$ & $\begin{array}{l}\text { Cullinane, Song, Ji } \\
\text { and Wang (2004) }\end{array}$ & DEA & $\begin{array}{l}\text { Shows that the efficiency of container terminals } \\
\text { fluctuates significantly over time. }\end{array}$ \\
\hline World & $\begin{array}{l}\text { Cross-section of } \\
40 \text { countries } \\
\text { (includes } 1 \\
\text { developing } \\
\text { country) } \\
1994\end{array}$ & $\begin{array}{l}\text { Notteboom, Coeck } \\
\text { and Van Den Broeck } \\
(2000)\end{array}$ & DEA & $\begin{array}{l}\text { Compares efficiency of } 36 \text { European terminals and } 4 \\
\text { Asian. Assessing the performance drivers, they find } \\
\text { that the most efficient are North European, the largest } \\
\text { terminals, the terminal in hub ports and the private } \\
\text { terminals. }\end{array}$ \\
\hline Asia & $\begin{array}{l}\text { Panel of } 15 \\
\text { countries } \\
1989-1998 \\
\end{array}$ & $\begin{array}{l}\text { Cullinane, Song and } \\
\text { Gray (2002) }\end{array}$ & SPF & $\begin{array}{l}\text { Shows that privatization has improved efficiency of the } \\
\text { Asian port system. }\end{array}$ \\
\hline India & $\begin{array}{l}\text { Panel of } 12 \text { Indian } \\
\text { ports } \\
1981-1982 \\
2000-2001\end{array}$ & De and Ghosh (2002) & TVPF & $\begin{array}{l}\text { Trying to explain the relation between productivity, } \\
\text { efficiency and technological change, they show that } \\
\text { increases in capital use improved productivity in India. }\end{array}$ \\
\hline Korea & $\begin{array}{l}\text { Cross section of } \\
11 \text { Korean ports } \\
1999\end{array}$ & Park and De (2004) & $\overline{D E A}$ & $\begin{array}{l}\text { Suggest a } 4 \text { stages DEA to highlight efficiency issues } \\
\text { ignored by simple DEA. }\end{array}$ \\
\hline Korea & $\begin{array}{l}\text { Panel of } 5 \text { Korean } \\
\text { and UK ports } \\
1978-1996\end{array}$ & $\begin{array}{l}\text { Song, Cullinane and } \\
\text { Roe (2001) }\end{array}$ & DEA & $\begin{array}{l}\text { Comparative assessment of Korean and UK container } \\
\text { terminals. Shows positive impact of increased private } \\
\text { sector participation. }\end{array}$ \\
\hline Mexico & $\begin{array}{l}\text { Panel of } 14 \\
\text { Mexican Ports } \\
1996-1999\end{array}$ & $\begin{array}{l}\text { Estache, González } \\
\text { and Trujillo (2002) }\end{array}$ & SPF & $\begin{array}{l}\text { Proposes a specific measure for the X of the Mexican } \\
\text { price cap adopted for the regulation of infrastructure in } \\
\text { the sector. Shows that the reforms improved that X } \\
\text { significantly in all ports. Suggests how X measure } \\
\text { could be used for yardstick competition. }\end{array}$ \\
\hline Mexico & $\begin{array}{l}\text { Panel of } 14 \\
\text { Mexican Ports } \\
1996-1999\end{array}$ & $\begin{array}{l}\text { Estache, Tovar and } \\
\text { Trujillo (2004) }\end{array}$ & DEA & $\begin{array}{l}\text { Shows how efficiency measures can be used to infer } \\
\text { demand shocks by illustrating the impact of the East } \\
\text { Asia crisis on the performance of ports authorities. }\end{array}$ \\
\hline
\end{tabular}

(*) SPF: Stochastic Production Frontier; DEA: Data Envelopment Analysis; TVPF: Time Varying Production Function. 
DEA tends to dominate the methodologies. There are however many methodological debates among port specialists and efficiency specialists. For instance, Park and De (2004) using data on 11 Korean ports for 1999 compare all the methods available and suggest a new 4 stages DEA to increase the robustness of the results. There is also a more conceptual debates on the number of port activities that need to be covered by efficiency studies. The matter is not a simple one since many of the activities are competitive while a few, more obviously the port infrastructure, are not. Moreover, while it is obvious to all that there is a complementarity between all activities, there is no uniform view on how to address it in the context of efficiency measures or even whether it needs to be addressed. For instance, some argue that all equipment, including equipment owned and operated by independent competitive providers, must be included in the assessment of the performance of the port authorities responsible for the basic infrastructure. Many more disagree with this vision arguing instead that there is an interest in assessing the performance of the regulated monopoly independently of the performance boost or penalty that independent competitive providers may generate. At best, when information is available, the competitive segments of the port should enter as environmental variables.

In practice, the response to the debate is generally settled by data availability. In general, the focus of the assessments in ports tends to be the production side rather than the cost side mainly because of data constraints. But these constraints are so binding that they also drive other choices. They explain why most articles focus on Cobb-Douglas rather than Translogs. Most studies also focus on data panels than time series. There are however a few very real policy aspects that cannot be ignored. For instance, most studies explicitly recognize the multiproduct nature of the port business, although a few focus on aggregate output measures. The most common is to see a disaggregation between general, dry-bulk, liquid-bulk and containerized cargo. On the input side, labor and capital tend to be present in every study. Everyone seems to agree on the labor variable but there is no consistency in the way the capital variable is being measured. Only a few studies have accounted for environmental variables (i.e. Is it a mainland port or an island? Is some of the cargo delivered by pipeline? ...).

It may be useful here to point to some very pragmatic implementation issues in the estimation of efficiency in the sector. It is not unusual also to see changes in the definitions of some of the variables during the periods of assessment. In the case of labor for instance, reforms tend to lead to major outsourcing policies. In this context, the employment data may end up comparing apples and oranges over time if the researcher is not careful. Indeed, the post reform data would only pick up employees under the port authority payroll and cover the others under the costs of service contracts. The risk is however limited for studies focusing on port authorities since they tend to be quite narrowly focused and are associated with very little outsourcing. For studies attempting to have a wider coverage of port services, the issue is more problematic.

With these limitations in mind, the few papers available provide a number of useful lessons. These can be separated in two types. From a market structure viewpoint, the research provides useful insights to any policymaker in developing countries. First, with respect to size, Cullinane et al. (2002) show that the size is directly influencing efficiency, at least in container terminals. Second, container terminals located in hub ports tend to be more technically efficient than those in feeder ports as documented by 
Notteboom, Coeck and Van den Broeck (2000). Third, Cullinane et al. (2004) point to the high degree of fluctuation of efficiency over time documented from a sample of 25 container terminals, including some in developing countries. This point is also made by Estache et al. (2004) when discussing the impact of the demand shock due to the East Asia crisis on the Mexican ports located on the Pacific coast of the country. Fourth, based on the Indian experience, De and Ghosh (2002) document the role of the access to capital and its degree of use to the level of efficiency of the sector comparing data from 1981-1982, and 2000-2001 for 12 Indian ports. Fifth, there are many factors driving the efficiency of a port. A few of the papers try to assess systematically the various sources of changes in efficiency. This is the case of Estache et al. (2004) for instance which computes a Malmquist TFP growth index and then relies on a distance function to decompose it into technical, scale and efficiency changes.

From a reform viewpoint, the main lessons are the following. First, the results on the relevance of ownership and the impact of reforms suggest that private ownership tends to improve efficiency in the sector in developing countries. Indeed, Cullinane, et al. (2002) show this in their analysis of 15 Asian container ports during the 1989-1998 period and Notteboom, Coeck and Van den Broeck (2000) reach similar conclusions. Second, increased competition and decentralization of port authorities improves efficiency as shown by Estache et al.. (2002 and 2004) in the case of Mexico. Third, benchmarking is a realistic regulation mode for the sector. Many of the papers are concerned with benchmarking some specific ports or port systems. Tongzon (2001) for instance compares the Australian ports to a set of best practice international ports for 1996 using a DEA. Estache et al. (2002) for instance shows how efficiency measures can be used to promote yardstick competition in the sector in a very pragmatic way. The analysis is done for 14 Mexican port authorities during the 1996-1999 period. The paper includes a discussion of how the use of efficiency measures can be used to shift the burden of proof on the operators in the context of scheduled or unscheduled tariff revisions. Container terminals located in hub ports tend to be more technically efficient than those in feeder ports as documented by Notteboom, Coeck and Van den Broeck (2000) .

\subsubsection{Railways}

The railways sector also suffers from a low coverage by the academic and regulatory literature offering quantitative assessment of economic efficiency in developing and transition countries as seen in Table 5. Technically, these papers are not very different from those on developed countries in terms of the choices of methodologies. Indeed, a few of them pool data from OECD and non-OECD countries to generate performance rankings in the sector.

Most of these papers deal with the two main characteristics of the railways sector which have long attracted the interest of researchers interested in measuring economic efficiency: multi-output production and natural monopoly. Railway companies have traditionally operated passenger and freight trains simultaneously on their own networks, either at the national or at the regional level. As seen in the Argentina and Brazil papers however, this was changed by the reforms of the 1990s in many countries. Indeed, in these two countries, long distance passenger service has essentially be reduced to a minimum. Intercity infrastructure is for freight and local suburban traffic is mostly 
passenger with a few instances in which tracks are shared locally-and regulatory conflicts arise.

Table 5: Railways

\begin{tabular}{|c|c|c|c|c|}
\hline Region & Data & Reference & Method (*) & Policy relevance \\
\hline World & $\begin{array}{l}46 \text { countries } \\
1998-2000\end{array}$ & $\begin{array}{l}\text { Lan and Lin } \\
(2003 \mathrm{a})\end{array}$ & DF & $\begin{array}{l}\text { Distinguishes between efficiency and service } \\
\text { effectiveness. } \\
\text { Focus on comparison of methodologies and } \\
\text { rankings. } \\
\text { Shows relevance of environmental variables. }\end{array}$ \\
\hline World & $\begin{array}{l}44 \text { countries } \\
1995-2001\end{array}$ & $\begin{array}{l}\text { Lan and Lin } \\
(2003 b)\end{array}$ & DEA & $\begin{array}{l}\text { Highlight relevance of non-traditional } \\
\text { performance indicators (e.g. sales } \\
\text { effectiveness relating to marketing). } \\
\text { Focus on comparison of methodologies and } \\
\text { rankings. } \\
\text { Argue that conventional models understate } \\
\text { productivity. } \\
\text { Shows relevance of environmental variables. }\end{array}$ \\
\hline World & $\begin{array}{l}85 \text { rail systems } \\
1999\end{array}$ & $\begin{array}{l}\text { Lan and Lin } \\
(2002)\end{array}$ & DEA/SPF & $\begin{array}{l}\text { Comparison of methods and their use. } \\
\text { Shows that LDC and transitions systems are } \\
\text { less efficient that OECD in a much larger } \\
\text { margin than expected. }\end{array}$ \\
\hline $\begin{array}{l}\text { America including } \\
\text { Brazil, Chile and } \\
\text { Mexico }\end{array}$ & $\begin{array}{l}5 \text { countries } \\
1980-1999\end{array}$ & Rivera-Trujillo & SPF (DF) & $\begin{array}{l}\text { Finds that technological change effect }(2.2 \% \\
\text { annual average) is higher than technical } \\
\text { efficiency for most countries. } \\
\text { South American have lower growth rather } \\
\text { than North America. }\end{array}$ \\
\hline Sub-Saharan Africa & $\begin{array}{l}9 \text { countries } \\
1970-1990\end{array}$ & $\begin{array}{l}\text { Mbangala and } \\
\text { Perelman (1997) }\end{array}$ & Sequential DEA & $\begin{array}{l}\text { Small companies and companies with higher } \\
\text { passenger shares perform better. }\end{array}$ \\
\hline Sub-Saharan Africa & $\begin{array}{l}10 \text { countries } \\
1970-1990\end{array}$ & $\begin{array}{l}\text { Mbgangala } \\
(2004)\end{array}$ & $\begin{array}{l}\text { Sequential DEA } \\
\text { and Malmquist } \\
\text { TFP index }\end{array}$ & Provides a regional ranking of operators. \\
\hline Sub-Saharan Africa & $\begin{array}{l}\begin{array}{l}1980-2001 \\
\text { national }\end{array} \\
\text { railways }\end{array}$ & $\begin{array}{l}\text { Mbgangala } \\
(2004)\end{array}$ & $\begin{array}{l}\text { Sequential DEA } \\
\text { and Malmquist } \\
\text { TFP index }\end{array}$ & $\begin{array}{l}\text { Updates previous ranking of operators. } \\
\text { Shows that Interconnection and multimodal } \\
\text { transportation need to be developed. }\end{array}$ \\
\hline Argentina and Brazil & $\begin{array}{lr}\text { Argentina: } & \\
\text { 1993-1999 } & 5 \\
\text { freight, } & 5 \\
\text { passenger } & \\
\text { Brazil: } & 1992- \\
\text { 1996 } & 6 \\
\text { freight } & \\
\text { companies } & \end{array}$ & $\begin{array}{l}\text { Estache, } \\
\text { Gonzalez and } \\
\text { Trujillo }(2001)\end{array}$ & TFP index & $\begin{array}{l}\text { TFP growth rates paths revealed the strategic } \\
\text { behavior of companies in a price-cap } \\
\text { regulatory regime. }\end{array}$ \\
\hline Brazil & $\begin{array}{l}6 \quad \text { freight } \\
\text { companies } \\
1992-2001\end{array}$ & $\begin{array}{l}\text { Estache, } \\
\text { Perelman and } \\
\text { Trujillo (2004) }\end{array}$ & $\begin{array}{lr}\text { DEA } & \text { and } \\
\text { Malmquist } & \text { TFP } \\
\text { index } & \text { with } \\
\text { quality-quantity } \\
\text { decomposition }\end{array}$ & $\begin{array}{l}\text { Incentive work when made as explicit as } \\
\text { possible in the design of regulatory regimes. }\end{array}$ \\
\hline
\end{tabular}

(*) SPF: Stochastic Production Frontier; EA: Data Envelopment Analysis; TFP: Total factor froductivity index number

A second interesting characteristic of this literature is that because cost minimization assumptions tend to be impossible to measure due to lack of data, most performance studies deal exclusively with physical output and input quantities and most are interested in production efficiency measurement only. In general ton-km or train-km are the main output measurements for freight and passenger-km for passengers. The main inputs tend to be employment, $\mathrm{km}$ of tracks - electrified or not--, rolling stock, energydistinguishing between the various sources. This very pragmatic approaches have not 
stopped the methodological debates as seen in the two papers by Lan and Lin (2003a and b) who echo many of the debates between researchers interested exclusively in OECD countries.

In terms of the main regulatory and policy lessons provided by this modest literature, the following stand out. First, all the multicountry studies highlight the importance of environmental factors in the absolute and relative performance of operators. Lan and Lin $(2002,2003 \mathrm{a}$ and $\mathrm{b})$ are quite keen to argue that case and do so effectively. The authors find great differences among companies as expected. The main contribution is however to show that these differences are partially explained by the degree of development (GDP per capita), the technology used ( $\%$ of electrified lines), and the density, both of the population and of the network lines. More dramatic maybe are the studies on SubSaharan countries (Mbangala and Perelman (1997) and Mbangala (2004a and b)). They reveal the strong impact on performance of the dramatic political disturbances in Africa. These disturbances are quite obvious in the railway performances of the national companies of Congo-Brazzaville (CFCO), Democratic Republic of Congo (SNCC) and Kenya (KRC) that suffered of great efficiency losses, mainly during the 1995 to 2001 period. Note that these authors also point out the dramatic increase in competition from the trucking industry resulting from improved road network coverage and the poor intermodal and inter-network coordination in Africa as important environmental variables they have not been able to pick up in their assessments.

Second, the literature also offers useful insights on the impact of reforms and in particular "privatization" of railways services. The results presented in Mbangala (2004a and b) also allow a comparison of the evolution of the performance of two railway companies privatized in 1999 (CEAR from Malawi and CAMRAIL from Cameroun). ${ }^{17}$ Both managed to stay in a good position close to the frontier too. But the author points out that both companies, like others in the sample, owe their improved performance to strong reductions in inputs (staff number and rolling stock) rather than improvements in outputs (passenger or tons kilometer transported). The author's conclusions highlight the main problems under scrutiny: organizational and management issues, maintenance problems in relation with the age of equipment (rolling stock and tracks).

The other two papers reported in Table 5 assessing the impact of reforms offer a contrasting story based on the experience of two of the most dynamic Latin American reformers in the sector: Argentina and Brazil. In both countries, the reforms undertaken in the 1990s consisted in the separation of passenger and freight transportation and, contrary to the European Union deregulation reform, no vertical separation between infrastructure and operation activities was introduced. Estache et al. (2001) estimate TFP growth indexes for Brazilian freight railways companies before and after privatization (around 1996) and find that improvements after the reform ( $8 \%$ by year) were mostly due to output increases, contrary to improvements before the reform (5.5\% by year) exclusively attributable to reduction inputs, particularly labor. In Argentina the freight and commuter networks were originally owned as an integrated public enterprise, therefore the comparison of performances before and after the reform are less informative. This is the reason why the authors estimate TFP growth indexes for the

${ }^{17}$ Other national companies in the sample were privatized as well but outside the period covered by the data, in 2002 and 2003 . 
period 1994 to 1999 after privatization exclusively. In both, freight and passenger transportation sectors, most companies reached high rates of productivity growth, 5.3\% and $9.8 \%$ on average, respectively. And, as in the case of Brazil's privatization, this increase is mainly concentrated on the output side. These results are globally confirmed by Estache et al (2004) with more recent data for Brazil.

Third, the literature also provides some useful insight on the timing of the efficiency effects of reform. In particular, Estache et al. (2001) also show that the major gains in efficiency realized by freight companies in Argentina and Brazil were achieved in the first year of operation. They also find that toward the end of the period efficiency drops for all the operators monitored. This tends to confirm the expectations derived from the use of price cap regimes with regular tariff revisions.

Fourth, the paper by Rivera-Trujillo compares the performance of the main North and Latin American railway systems and finds that between 1980 and 1999, the South lagged the North significantly on all efficiency counts. Particularly interesting is the observation that it also lagged the North in terms of the internalization of technological change. On average also, for that continent and during that period, technological change was higher than technical efficiency change.

Fifth, the recent paper by Estache, Trujillo and Perelman (2004) points to the importance of an integrated approach in dealing with safety and output concerns in the regulation of railway service. They do so by modeling an interesting innovative feature of the Brazilian "privatization" intended to ensure a close monitoring of the quantity-quality trade-off. With a price cap regime in the background, the privatization team spelled out, for each concession, two specific targets about output and safety, in terms of minimum net ton-kilometers carried each year and maximum number of accidents per trainkilometer during the first five years. The modeling approach relies on a non-parametric (DEA) index, introduced by Färe et al. (1995), which shows how operators chose between output and quality. The most relevant results reported in Estache et al. (2004) show that the contribution of quality, represented by safety and speed indicators, to productivity change was negative during the public management and transition periods, $0.7 \%$ and $-2.3 \%$ a year, respectively, while it contributed positively to productivity change, $3.9 \%$ a year, during the last period after the reform. In other words, private operators have improved efficiency in terms of both quantity and quality.

Finally, the various papers covering large sets of countries providing both passenger and freight services provide useful insights on the relevance of the size of the network and the complexity of the operations. One of the main results in Mbangala and Perelman (1997) for instance is that on average, small companies and companies operating proportionally higher shares of passenger transport perform better.

\section{The measurement of efficiency for regulators is a competitive business}

It may be useful in this survey to point out that the market of efficiency measures for regulators is much more competitive than often assumed. Stochastic or deterministic frontiers or DEAs are not the only game in town. There is indeed an increasing presence 
of alternatives to standard economic efficiency measures in "real life" regulatory processes.

The most common form of alternatives are engineering-economic models developed in recent years as an alternative to the traditional econometric and accounting approaches to cost assessments. Engineering models offer a more detailed view of cost structures than is possible using econometric data. Because econometric models rely on assumptions of (smooth) functional forms, engineering process models offer a more detailed view of cost structures than is possible using econometric data.

There are two approaches. The first is common in the telecom sectors. Since the 1996 US telecom reforms, a number of countries have relied on forward-looking cost proxy models based on a best practice optimization model of investments in the sector. In practice, these economic cost proxy models begin with an engineering model of the physical local exchange network, and then makes a detailed set of assumptions about input prices and other factors. These hybrid cost models are increasingly being used or at least considered by Latin American and African telecoms regulators to assess forwardlooking efficient costs in the context of the assessment of regulatory decisions associated with universal service obligations or interconnection charges. ${ }^{18}$ Some of the consultants who worked on these models are now trying to develop equivalent products for the energy sector.

A second type of engineering model used more in the water and energy sectors in some of the Latin American countries is the "model-operator" model. In a nutshell, the model-operator model is the idealization of the operation of a business by engineers and focuses on production processes and the best practice associated costs. Chile in Latin America (and Spain in Europe) has tried it in some of its regulated activities. It is now also being used in Argentina as part of the definition of the government position in some of its utility contract renegotiations. Bustos and Galetovic (2002) provide an overview of the various aspects of this approach in the Chilean context. Grifell-Taje and Lovell (2003) offer a very useful comparison of the "ideal distribution network" as designed by a consultancy firm with the efficiency estimated from traditional "economic" techniques for Spain's electricity system. They show that the ideal network would have been in 1996 about $29 \%$ less costly to operate but that the incumbent managers were actually more cost efficient than the "ideal model" being more effective at exploiting opportunities for improvements in allocative efficiency under the existing regulatory regime.

Both approaches seem to still be fairly specialized but they need to be seen as indicators that there are many ways of getting to the efficiency measure to be used in any incentive based regime.

\section{Concluding comments}

All things considered, while the list of papers covered by the survey is relatively short, it provides quite an interesting set of lessons. The lessons to be drawn are of two types: policy and technical.

\footnotetext{
${ }^{18}$ For a quick read on the topic, see Benitez et al. (2004) or Laffont, et al (2003)
} 
At the policy level, the main lesson may be the difference in the relevance of ownership for efficiency between utilities and transport. In transport, private operators have tended to perform better than public operators in developing countries. For utilities, it seems that in general ownership often does not matter as much as sometimes argued. Most cross-country papers on utilities find no statistically significant difference in efficiency scores between public and private providers. As for the country specific papers, some do find differences in performance over time but these differences tend to matter much less than a number of other variables. Across sectors, the more relevant variables include the degree of competition, the design of regulation, the quality of institutions and the degree of corruption. A second lesson is that incentives work. Indeed, across sectors, private operators functioning in a competitive environment or regulated under price caps or hybrid regulatory regimes tend to catch up faster than public operators. There is however no obvious difference in terms of frontier shift. A third policy lesson is that there is a very strong case to push regulators in developing and transition economies toward a more systematic reliance on yardstick competition in a sector in which residual monopoly powers tend to be common. The use of these methods for simple rankings is quite widespread. It could go one step further as it has done in some OECD countries and use the information generated to actually drive cost and hence prices lower.

At the very technical level, to state the obvious, analysts interested in the efficiency of infrastructure services in developing and transition economies tend to have more data problems than analysts focusing on developed economies. Only a few countries are managing to generate analyses of quality comparable to those observed in OECD countries. Most are in Latin America. Moreover, among the 4 sectors covered here, only the energy sector seems to have enough information to allow the generation of policy relevant analyses comparable to those available for OECD countries.

There are three main data problems. The first is the measurement of capital. This problem is however not a simple one even in developed economies. ${ }^{19}$ The size of the problem is however somewhat surprising for recently privatized operators in view of the fact that typically, privatizations involve in-depth assets valuations. The second is the difficulty of modeling correctly the size of employment in view of the increased trend to outsource many activities in this sector. The third data problem comes from the poor accounting standards of most developing countries and the weak commitment to regulatory accounting standards by privatization teams who seem to sometimes be more interested in the deals than in their sustainability. Most of these problems can be handled through assumptions, tests designed to ensure the robustness of the results or refocusing of efficiency assessments towards results with which analysts feel comfortable. However, the more technical the debate becomes, the larger the wedge between the supply of efficiency analysis and the demand by regulators.

The need to address this wedge is a serious challenge, and may not be specific to developing country regulators. In general, the supply of efficiency work seems to be dominated by overly technical papers. Yet, the demand from the incentive based regulation is for specific assessments of potential cost reductions which can be passed on to users and by a concern for an unbundling of the source of changes in efficiency

\footnotetext{
${ }^{19}$ Coelli et al. (2003) allocated a 13 pages annex to the issue in their book targeted to infrastructure regulators.
} 
between those that can be addressed by regulators and those that cannot. In a nutshell, regulators generally want to know about average rates of change and their decomposition more than anything else.

The mismatch between the demand and the supply may reflect the fact that the "efficiency practice" is generally made of econometricians or mathematicians with little training in real world economic regulation while the "efficiency users" are generally regulatory economists, engineers or lawyers and other specialists with not enough quantitative skills. Oversimplifying the supply to meet the demand will not do much good to the fairness of regulation but shooting for perfection is likely to ration the demand because it is likely to be overly technical. The challenge is for the "practice" to move toward the demand while minimizing the concessions to quality standards. This challenge is the bread and butter of any applied economist hoping to be policy relevant without sacrificing his/her academic credibility. 


\section{References}

1. Alva, S.L. and J.L. Bonifaz (2001), "Eficiencia relativa en el servicio de saneamiento en el Peru durante el periodo 1998-2000: una aplicación del DEA", mimeo, Universidad del Pacifico

2. Agencia Nacional de Energia Electrica (Aneel) (2003), "Nota Técnica No178", available on www.aneel.gov.br

3. Bagdadioglu, N, C.Price and T.Weyman-Jones (1996), Efficiency and ownership in electricity distribution: a non-parametric model of the Turkish experience", Energy Economics, 18(1-2), 1-23

4. Benitez, D., A. Estache, M. Kennet and C. Ruzzier (2002), "The Potential Role of Economic Cost Models in the Regulation of Telecommunications in Developing Countries", Information Economics and Policy, March, Vol 14, No.1 21-38

5. Berg, S., C. Lin and V. Tsaplin (2004), "Regulation of State-Owned and Privatized Utilities: Ukraine Electricity Distribution Company Performance", PURC, University of Florida

6. Bogetoft, P. (1997), DEA-based yardstick competition: the optimality of best practice regulation", Annals of Operation Research, 73, 277-298

7. Bogetoft, P. (2000), DEA and activity planning under asymmetric information", Journal of Productivity Analysis

8. Bustos, A. and A. Galetovic (2002), "Regulación por empresa eficiente: ¿quién es realmente usted?, Estudios Públicos 86, otoño, 145-182

9. Clarke, X., D. Dollar and A. Micco (2004), "Port efficiency, maritime transport costs and bilateral trade", Journal of Development Economics, 75, 417-450

10. Coelli, T. A. Estache, S. Perelman and L. Trujillo (2002), A Primer on Efficiency Measurement for Utilities and Transport Regulators, WBI Development Studies, Washington, DC.

11. Colson, G. and A. Mpapa Mbangala (2003), "Telecoms reform and Productivity Changes in Africa in the 1990s", Document de Recherche, Université de Liège

12. Corton, M.L. (2003), "Benchmarking in the water sector: the case of Peru", Utilities Policy, 11, 33-142

13. Comisión de Regulación de Energía y Gas (CREG) (2002), "Análisis de Gastos Eficientes de Administración, Operación y Mantenimiento, AOM, en Distribución de Energía Electrica", Colombia, available at http://www.creg.gov.co/

14. Cullinane, K., D.W. Song and R. Gray (2002), "A stochastic frontier model of the efficiency of major container terminals in Asia: assessing the influence of administrative and ownership structures" Transportation Research, Part A: Policy and Practice, 743-762

15. Cullinane, K., D.W. Song, P. Ji and T.F. Wang (2004), "An Application of DEA Windows Analysis to Container Port Production Efficiency". Review of Network Economics. Vol. $3 \mathrm{~N}^{\mathrm{o}} 2$.

16. Das, N. (2000), Technology, efficiency and sustainability of competition in the Indian Telecommunications sector", Information Economics and Policy, 12, 133-154

17. De, P. and B.Ghosh (2002), "Productivity, efficiency and technological change in Indian ports". International Journal of Maritime Economics .Vol.4, 348-368. 
18. Domah, P. (2002), Technical Efficiency in Electricity Generation-The impact of smallness and isolation of island economies", Cambridge Working Papers in Economics, CMI working paper 14

19. Estache, A. and M. Rossi (2004), "Do Regulation and Ownership Drive the Efficiency of Electricity Distribution? Evidence from Latin America", Economic Letters, (forthcoming)

20. Estache, A. , M. Rossi and C. Ruzzier (2004), "The Case for International Coordination of Electricity Regulation: Evidence from the Measurement of Efficiency in South America", Journal of Regulatory Economics, May, pp. 271-295

21. Estache, A. and A. Goicoechea (2004), "Notes on the state of infrastructure reforms in developing and transition economies", World Bank, mimeo

22. Estache, A., S. Perelman and L. Trujillo (2004), "Measuring Efficiency-Quality Trade-offs: An Application to Brazil's Freight Railways”, VIIIth European Workshop on Efficiency and Productivity Analysis meeting, Oviedo, September 2003

23. Estache, A., B. Tovar and L. Trujillo (2004), "Sources of Efficiency Gains in Port Reform: A DEA Decomposition of a Malmquist TFP Index for Mexico", Utilities Policy, December.

24. Estache, A., J.L. Guasch and L. Trujillo (2003), "Price caps, efficiency pay-offs and infrastructure contract renegotiation in Latin America", in Bartle, I., The UK Model of Utility Regulation: a 20th anniversary collection to mark the "Littlechild Report" retrospect and prospect, CRI Proceedings 31

25. Estache, A. and L. Trujillo (2003), "Efficiency effects of "Privatization" in Argentina's Water and Sanitation Services", Water Policy, 5 (4), 369-380

26. Estache, A. and M. Rossi (2002), "How different is the efficiency of Public and Private Water Companies in Asia", The World Bank Economic Review, . 16(1), 139148

27. Estache, A. and E. Kouassi (2002), "Sector Organization, Governance and the Inefficiency of African Water Utilities", World Bank Policy Research Working Paper, No3374

28. Estache, A., M. Gonzalez and L. Trujillo (2002), "Efficiency Gains from Port Reform and the Potential for Yardstick Competition: Lessons from Mexico", World Development, 30 (4), April, 545-560

29. Estache, A., M. Gonzalez and L. Trujillo (2002), "What Does Privatization Do for Efficiency? Evidence from Argentina's and Brazil's Railways", World Development, 30 (11), November, 1885-1897

30. Facanha, L.0. and M. Resende (2004), "Price Cap Regulation, Incentive and Quality, The case of Brazilian Telecommunications", International Journal of Production Analysis, vol. 92, 2, November, 133-144

31. Filippini, M, N. Hrovatic and J. Zoric (2004), "Efficiency and regulation of the Slovanian electiricty distribution companies", Energy Policy, 32, 335-344

32. Frontier Economics and Macroconsulting (2001), " Benchmarking Efficiency: EDELAP Price Review”, Initial Report Prepared for ENRE

33. Gasmi, F., D. M. Kennet, J.J Laffont and W.W. Sharkey (2002), Cost proxy models and telecommunications policy: A new empirical approach to regulation, The MIT Press, Cambridge, MA. 
34. Gasmi, F., J.J Laffont and W.W. Sharkey (2002), "The natural monopoly test reconsidered: an engineering process-based approach to empirical analysis in telecommunications", International Journal of Industrial Organization, Vol. 20, 4, April, 435-459

35. Gasmi, F., J.J Laffont and W.W. Sharkey (2000), Competition, universal service and telecommunications policy in developing countries, Information Economics and Policy, Vol. 12, 3, September , 221-248

36. Gonzalez, M., B. Tovar and L. Trujillo (2004), "Eficiencia de los puertos europeos", mimeo, Universidad de Las Palmas de Gran Canaria

37. Gonzalez, M. And L. Trujillo (2004), Reforms and Infrastructure Efficiency in Spain's Container Ports, paper presented at the 3rd Infrastructure Conference in Berlin, October.

38. Grifell- Tatjé, E. and K. Lovell (2003), "The Managers Versus the Consultants", Scandinavian Journal of Economics 105:1 (2003), 119-38

39. Guasch, J.L (2004), Granting and renegotiating infrastructure concessions: Doing it right, WBI Development Studies, Washington, DC

40. Gutierrez, L.H. (2003), "The effects of endogenous regulation on telecommunications expansion and efficiency in Latin America”, Journal of regulatory economics, 23:3, 257-286

41. Jasmab, T. and M. Pollitt (2001), "Benchmarking and regulation: international electricity experience", Utilities Policy, 9, 107-130

42. Kirpatrick, C. D. Parker and Y-F. Zhang (2004), "State versus Private Sector Provision of Water Services in Africa: An Empirical Analysis", University of Manchester, Centre on Regulation and Competition, Working Paper Series, Paper No70, June

43. Lam, P.L. and A. Shiu (2004), "Efficiency and Productivity of China's Thermal Power Generation", Review of Industrial Organization, 24 (1), pp73-93, Feburary

44. Lam, P.L. and A. Shiu (2001), "A data envelopment analysis of the efficiency of China's thermal power generation", Utilities Policy, 10, 75-83

45. Lan and Lin (2003a), "Technical efficiency and service effectiveness for railways transport: Distance Functions approaches", Institute of Traffic and Transportation, National Chiao Tung University, Taiwan, mimeo,

46. Lan and Lin (2003b), "Measuring the railway efficiency, effectiveness productivity and sales force with adjustment of environmental effects, data noise and slacks", Institute of Traffic and Transportation, National Chiao Tung University, Taiwan, mimeo, paper presented at the Asia Pacific Productivity Conference 2004, Brisbane, Australia

47. Lan and Lin (2002), "Measuring Technical and Scale Effieincy in Rail Industry: A comparison of 85 Railways Using DEA and SFA", Traffic and Transportsation, No21, pp75-88

48. Lavado, R (2004), "Benchmarking the efficiency of electricity cooperatives using stochastic frontier analysis and DEA", Asian Public Policy Program, Hitotsubashi University, mimeo

49. Mbangala, M.A. (2004), "Management of railways in Sub-Saharan Africa Railway productivity analysis", Rail International, 12/2 
50. Mbangala, M.A. (2001), Le transport ferroviaire en Afrique noire. FonctionnementPerformances - Perspectives, Editions de l'Université de Liège.

51. Mbangala M.A. and S. Perelman (1997), L'efficacité technique des chemins de fer en Afrique Subsaharienne: une comparaison internationale par la méthode DEA (Technical efficiency of the railways in Sub-Saharan Africa: international comparison using the DEA method), Revue d'Economie de Développement, 3/93, pp.91-115.

52. Meibodi, A.E. (1998), "Efficiency considerations in the electricity supply industry:" The case of Iran", Surrey Energy Economics Discussion Paper Series, SEEDS 95, University of Surrey

53. Melo, L.B. and N. Espinosa (2004), "Inefficiencia en la distribucion de energia electrica: una aplicacion de las funciones de distancia estocasticas", mimeo, Bogota.

54. Motta, R. L. (2004), "Comparing Brazil and USA Electricity Distribution Performance: What was the impact of privatization", Cambridge Working Papers in Economics, CMI working paper 39

55. NERA (1997), "Estimacion del Factor de Eficiencia X", Report prepared for the Gas sector regulador (ENARGAS), January

56. Notteboom T., C. Coeck, and J. Van Den Broeck (2000), "Measuring and Explaining the Relative Efficiency of Container Terminals by Means of Bayesian Stochastic Frontier Models". International Journal Maritime.Vol. II, (2), 83-106.

57. Pacudan, R. and E.de Guzman (2002), "Impact of energy efficiency policy to productive efficiency of electricity distribution industry in the Philippines", Energy Economics, 24, 41-54.

58. Park, R. K. and P. De (2004); “An Alternative Approach to Efficiency Measurement of Seaports". Maritime Economics \& Logistics . Vol. 6, No 1, 53-69.

59. Plane, P. (1999), "Privatization, Technical Efficiency and Welfare Consequences: The Case of the Cote d'Ivoire Electricity Company", World Development, 27(2), 341360.

60. Pollitt, M. (1995), Ownership and Performance in Electric Utilities: the International Evidence on Privatisation and Efficiency, Oxford University Press, Oxford

61. Pombo, C. and Ramirez (2002), "Privatization in Colombia: A Plant Performance Analysis", Universidad del Rosario. Departamento de Economia, Serie Documentos, Borradores de Investigacion, Colombia, No 21.

62. Pombo, C. and Ramirez (2002), "Performance and Efficiency in Colombia's Power Utilities: An Assessment of the 1994 Reform", Universidad del Rosario. Departamento de Economia, Serie Documentos, Borradores de Investigacion, Colombia, No 40.

63. Resende, M. (2002), "Relative efficiency measurement and prospects for yardstick competition in Brazilian electricity distribution", Energy Policy, 30, 637-647

64. Resende, M. and L.O. Facanha (2004), "Privatization and efficiency in Brazilian Telecommunications: An Empirical Study", Applied Economic Letters, 9, 820-826

65. Rivera-Trujillo (2003), "Measuring efficiency in North and South American Railways using a Stochastic Frontier Model: an international comparison", mimeo, Institute for Transport Studies, University of Leeds

66. Rodriguez-Pardina, M. and M. Rossi (2000), "Fronteras de eficiencia en el sector de distribución de energia electrica: la experiencia sud-americana”, Anais do XX Encontro Brasileiro de Econometria, 24, 367-392 
67. Rodriguez-Pardina, M. and M. Rossi (2000), "Technical Change and Catching-Up: The Electricity Distribution Sector in South America", Working Paper No.11 (November), Centro de Estudios Economicos de la Regulacion, Universidad Argentina de la Empresa

68. Rossi, M. (2001), "Technical change and efficiency measures: the post-privatization in the gas distribution sector in Argentina", Energy Economics, 23, 293-305

69. Sanhueza, R., Rudnick, H., Discussion of "Performance Evaluation of Electric Distribution Utilities Based on Data Envelopment Analysis", IEEE Transactions on Power Systems, Vol. 18, No. 3, pp. 1220-1221, August 2003

70. Sanhueza, R.; Rudnick, H.; Lagunas, H., "DEA Efficiency for the Determination of the Electric Power Distribution Added Value", IEEE Transactions on Power Systems, Volume: 19 , Issue: 2, pp. 919 - 925 , May 2004

71. Seroa da Motta, R. And A.R.B. Moreira (2004), "Efficiency and regulation in the Sanitation Sector in Brazil", IPEA, Texto Para Discussao, No 1059

72. Song, D.W., K. Cullinane and M. Roe (2001), The Productive Efficiency of Container Terminals; an Application to Korea and the UK. Ashgate Publishing Co.

73. Tongzon, J. (1994), "An evaluation of ASEAN port performance and efficiency", Asian Economic Journal, 8(3), 317-330

74. Tongzon, J.L. (2001). "Efficiency Measurement of selected Australian and Other International Ports Using Data Envelopment Analysis", Transportation Research, part A, 35, 113-128.

75. Tupper, and M. Resende (2004), "Efficiency and regulatory issues in the Brazilian water and sewage sector: an empirical study", Utilities Policy, 12, 29-40

76. Ugaz, C. and C. Waddams Price, Utility Privatization and Regulation: A Fair Deal for Consumers? Edward Elgar, Northampton, MA, USA.

77. Whiteman, J. (1995),'Benchmarking developing country electricity systems using data envelopment analysis", Asia-Pacific Economic Review, 1(3), 71-78

78. Whiteman, J. (1998), "The potential benefits of Hilmer and related reforms: electricity supply", Centre of Policy Studies and the Impact Project, Monash University, General Paper, No G-128

79. Yumos, J.M. and D. Hawton (1998), The efficiency of the national electricity board in Malaysia: an intercountry comparison using DEA", Energy Economics, 19, 255269 